This is an Accepted Manuscript of an article published firts on-line by Taylor \& Francis in Research Papers in Education on 11.7.2013, available online:

http://www.tandfonline.com/10.1080/02671522.2013.813579

Fontich, X. \& Camps, A. (2014) Towards a rationale for research into grammar teaching in schools, Research Papers in Education, 29:5, 598-625, http://dx.doi.org/10.1080/02671522.2013.813579

\title{
Towards a rationale for research into grammar teaching in schools
}

\author{
Xavier Fontich* \& Anna Camps** \\ *Universitat Autònoma de Barcelona \\ ** Universitat Autònoma de Barcelona \\ *Corresponding author. Email: xavier.fontich@uab.cat
}

\begin{abstract}
This article hopes to bring new insights to the debate about the effect of grammar knowledge on language use, especially writing. It raises the question of the need to look more closely at the following three questions: (1) What is the aim of grammar teaching?; (2) How capable are students of conceptualising about language and how is their metalinguistic activity shown in their language use?; and finally, (3) Which approach is most suitable for students to be able to develop their own knowledge, with emphasis on the role of interaction in the classroom? The article concludes with ten key points which provide a basic outline for progressing in grammar teaching research. Keywords: grammar teaching; metalinguistic activity; grammar teaching content; classroom approaches; pedagogical system
\end{abstract}

\section{Introduction}

Language teaching has been reviewed many times during the twentieth century, firstly in relation to the way linguistics has evolved and its fields of research have diversified, and secondly in relation to an ever-growing need to develop the verbal, oral and written skills of students. As pointed out by Charolles and Combettes (2001), western tradition in language teaching comes from an initial separation of rhetoric and grammar in classical studies into language, which has had repercussions both in theoretical studies (Charolles and Combettes speak of 'disjunction') as well as in teaching. According to Bronckart (2008), in schools, what has been called traditional gramar adopted a series of school routines which revealed themselves as incapable of becoming an adequate tool for language learning, both in terms of the linguistic system and verbal use. The twentieth century saw the emergence of formal grammar, and this had a profound effect in schools in its numerous adaptations. 
However, the introduction of certain structural and generative grammar requirements stressed the separation of school grammar from language use, even the use of formal language. Schools demanded that more importance be given to teaching how to use language, especially reading and writing. New references, arising from psychology and the study of cognitive processes as well as from linguistics and studies into rhetoric, have been key factors in diversifying teaching references in the fields of language sciences (new rhetoric, studies on enunciation, text and discourse, etc.). In the curricular reform processes, which attempt to find answers to students needs and in which the importance of learning the use of language is gaining ground, the place held by grammar teaching has been, and continues to be, a source of controversy.

The debate, although widespread in the western world, has not taken the same form in all countries, although a common point is found in the different contexts: the question of whether teaching grammar in schools could be a useful tool for helping in progressively mastering verbal competence, especially written skills. It could therefore be said that the debate has two sides, on the one hand the position defended by those who believe that knowing the grammar of a language is of Little or no importance in learning to read and write that language, and on the other hand, that argued by those who consider it an essential part of the process.

In order to understand the role of grammar knowledge in learning to write, we defend the need to take into account and integrate three different issues: firstly, a model of pedagogic grammar inspired on functional linguistic perspectives; secondly, the consideration of metalinguistic activity as the basis and the tool for developing reflection about language; and thirdly, an approach to classroom activities based on interaction, and focused both on the use of language and on the student's metalinguistic capacities. Our aim in this paper is to present the debate on grammar teaching and to develop a rationale for research into grammar teaching in schools which integrates these three dimensions.

\section{A debate on grammar teaching}

In English-speaking countries, there has been extensive discussion among those in favour and against the explicit teaching of grammar as a tool for improving reading and, especially, writing skills (Carter 1990; James 2002; Locke 2010), often with very significant ideological derivatives (Cameron 1995). This argument, which in some countries has swung from one extreme to the other, has generated a body of very diverse research (Hudson 2001; Wyse 2001; Locke 2009, 2010) Some studies have had the intention of determining the effect that the explicit study of gramar has on 
written composition from a positivist perspective, which could be qualified as being part of applied linguistics and psychology. These studies are focused on quantitative results that depend on the characteristics of the products, without taking into consideration the teaching and learning situations experienced by learners. Andrews, Torgerson, Beverton, Locke et al. (2004), Andrews, Torgerson, Beverton, Freeman et al. (2004), and Andrews (2010), in tune with other studies (Morenberg, Daiker, and Kerek 1978; Strong 1986; Hillocks and Smith 2003; Killgallon and Killgallon 2006), come to two conclusions: (a) that the explicit teaching of gramar is of no help in improving writing skills; and (b) that, conversely, the study of sentence-combining is indeed beneficial. From this second conclusion, we can gather that the authors do not consider sentencecombining activities as a type of gramar teaching. However, from our point of view the underlying idea which can be taken from this conclusion is that sentence manipulation exercises promote implicit metalinguistic activity (cf: Section 3 on metalinguistic activity). Proposals, like those of Weaver (2008) or Kolln and Gray (2010), to teach grammar in order to develop writing skills would have the same perspective and defend grammar teaching with varying degrees of explicitness orientated towards its use. Locke (2009) and Hudson (2001), however coincide in considering that it is better to keep the question open. They point out that the studies from which these conclusions have been drawn vary greatly in terms of how the research has been conceived and how both grammar teaching and learning are perceived. Hudson cites the groundbreaking work of Laurinen $(1955$, quoting Hudson 2001, 3) focusing on Finnish schoolchildren, which underlines the need to explore to what degree the teaching of grammar has an effect.

This research takes into consideration the following variables: the content, the period of time devoted to studying grammar and in what class/at what age the study begins. The proposals made by Carter (1990) and Bain, Fitzgerald, and Taylor (1992) coincide with this line of thinking, as do the experiences analysed by Freeman and Freeman (1998), Janks (2010) or Myhill et al. (2012). All of them, from different positions, consider it essential to focus explicitly on grammar in order to help schoolchildren to organise coherent grammar knowledge, i.e. that the concepts should be organised to form a simple and comprehensible system. Explicit grammar teaching has always been considered a key element in teaching schoolchildren in the Frenchspeaking tradition. It was in France that a proposal for school grammar derived from generative grammar (Dubois 1969) was adopted universally. It was also in France that research showed that the grammar being taught in schools, based on the aforementioned principles, does not contain the right elements in order to be effective for the reading and writing of texts (Vargas and Grossman 1996) The relationship 
between implicit and explicit grammatical knowledge is discussed (Nadeau and Fisher 2011). More recently, the need for a grammar that improves the use of language has become more important and more widely accepted (Combettes 2009). The 'new grammar' (grammaire nouvelle), which was incorporated into the curricula in Québec in 1995 (Nadeau and Fisher 2006), has formal linguistics as its reference. It tackles the question from the textual dimension, combining morphologic, syntactic and to a lesser degree semantic criteria, in order to define categories and functions. However, some authors (Bain and Canelas-Trevisi 2009; Combettes 2009) claim that a new school grammar, which incorporates oral and written notions in a homogeneous context, identifying the most pertinent concepts for oral communication, is yet to be designed and tested.

For Vargas (2009), this new grammar teaching focus must take into consideration the relationship between syntax, semantics and enunciation with regard to both the definition of concepts as well as the procedures for language analysis. Charaudeau (2009) explores the close relationship which exists between language, discourse, text and context to overcome the dichotomy between the theoretical approach to the language system and the ethnographical approach to communication. In the same vein, Bronckart (2008) points out that discursive rules condition the syntax and some other morphological aspects and not vice versa, and he calls for a more unified vision of linguistic phenomena.

In Spain, the ground-breaking study by Camps (1986) developed and presented the idea of introducing basic grammar concepts in the early stages of primary school education, and made a proposal to this effect. The aim was to develop infants' ability to understand language as a form of observation (differences in meaning related to form, change in context, sentence manipulation, etc.). However, in this country the majority of those involved in the research and development of language teaching do not consider grammar knowledge as important for developing verbal competence. This is clearly evident since grammar has nearly disappeared from the curricula in some of the autonomous communities 1 in Spain, and also due to the lack of articles written on the role of grammar in teaching in language teaching journals between 1990 and 1999 (Notario 1999). Going against the general current trend, there are only a few research groups2, teachers' and teacher training groups taking as a starting point the idea that writing activities require metalinguistic reflection and developing teaching models with a higher grammar content. This is done both by means of writing activities and by implementing didactic sequences where the learning objects deal with grammar contents. From a functional perspective, Zayas (1997) and Rodríguez and Zayas (1994) explore discursive types as a link between grammar reflection and 
metalinguistic use, being aware of the limits of the grammar of the sentence for acknowledging the linguistic, textual and discursive phenomena. Without abandoning use-orientated grammar teaching, Camps (1998), González Nieto (2001), Zayas (2004), and Camps et al. (2005), consider the usefulness of exploring the grammatical concepts needed to improve the understanding of the use of language in order to communicate, as well as the procedures for teaching and learning these concepts. This brief overview of grammar teaching in schools has given rise to a number of questions, which we believe are fundamental in working towards our aim: (a) providing students with the analytical tools that will allow them to observe and improve verbal use and (b) constituting a simple, basic framework in order to ensure that the knowledge acquired is both functional and universal. The following are the main questions raised that require further research. Our aim is simply to contribute to and enrich the debate about the relationship between learning grammar and learning to write:

(1) What are the characteristics of a grammar suited to the needs of what is expected at school level? What should the references be? Could a change in the grammar content have an effect on writing skills?

(2) What is the relationship between declarative knowledge and procedural knowledge? How do students define the grammar concepts? What role does terminology play in this process?

(3) Is it possible that a change in the content of grammar teaching which gives equal consideration to its form, semantics and pragmatics provides useful grammar concepts for students?

Firstly, question (1) refers to the concept of pedagogical grammar. With regard to metalinguistic activity and conceptualisation (question 2), we also need to understand the features of students' metalinguistic activity at the different levels. For example, activities dealing with sentence-combining would constitute a metalinguistic activity at a basic level, and this would also need to be integrated into what we understand as grammar activities. Finally, with regard to classroom procedures (question 3); grammar must introduce students to activities which allow them to observe and manipulate linguistic forms so that they can understand the abstract concept. This is essential if it is to be a tool that allows them to reflect on its use. Asking the questions (1) and (2) should aid in clarifying the debate and focus the topic on the relationship between grammar knowledge and language use for schools. Asking the question (3) should also lead to a line of research addressed at ways of implementing this relationship at school. These questions will allow us to design and draw up an action plan for grammar teaching and learning in the classroom. In order to establish such a model, we need to take into consideration a number of factors which 
have arisen in teaching proposals or in research projects, but have never really been considered together.

In the following sections, we will refer to (a) the metalinguistic activity implied in linguistic conceptualisation, (b) the aim of grammar teaching and (c) the approaches in the classroom to grammar teaching. Finally, we present the essentials of a reflexive grammar-teaching model for language use (especially in the written form).

\section{Metalinguistic activity and conceptualisation}

All speakers, in parallel to the learning and developing of language itself, learn about language. This can be seen in the way they control its productions (reformulations, doubts and amendments) and also in the way they are able to judge the productions of others. Moreover, literate societies have developed a shared, formalised knowledge of linguistics born from and designed to respond to social needs (education, the study of texts, etc.), and have created highly formalised scientific models.

Generally speaking, metalinguistic knowledge refers to knowledge about language. That is, it is the linguistic activity whose referent is language and linguistic activity itself. However, the term 'metalinguistic' and the associated concepts have been addressed from a diversity of perspectives. A sign of such diversity are the nouns associated with the adjective 'metalinguistic', related to the scientific area they are associated with and its underlying theoretical concept. Hence, the plethora of studies on this issue talks about metalinguistic function, faculty, capacity, representation, reflection, activity, analysis, control and knowledge. We will refer to some of these below, and will end up expounding a perspective that we consider effective for exploring knowledge about language in schools and the teaching of grammar.

Following Camps et al. (2005), we consider that the major contributions to the area of 'metalinguistics' are either linguistic or psycholinguistic. The term 'metalinguistic' appears as early as the fourth century B.C., but its diffusion in modern times is due to logic and mathematical linguistics. This term is incorporated into the field of linguistic studies together with structural linguistics, especially through the works of Jakobson (1960) and the Linguistic Circle of Prague. Jakobson defines the functions of language in relation to the individual's behaviour. First of all, he distinguishes the communicative function (focusing on meaning) and the poetic function (focusing on form). It is, in part, this poetic function that will become the metalinguistic function. The linguists discourse about language clearly corresponds to a 
metalinguistic function, but this function also appears in daily speech, and has an important role in language acquisition. As Jakobson points out $(1960,120)$, speakers practise metalinguistic function without being aware of it, just like Molière's Monsieur Jourdain, who used prose without knowing it. Other authors have studied the linguistic forms belonging to this function.

Rey-Debove (1978) refers to 'natural metalanguage' which is nothing more than everyday speech about language, especially about the words used by others. Psycholinguistics has also shown interest in metalinguistic function. While linguists see metalinguistic activity as simply 'language on language', psycholinguists consider metalinguistic activity as 'language cognition', as an integral part of the individual's cognitive activity. Therefore, its studies are oriented less towards the linguistic forms than to the human capacity for conceptualising these forms, for taking them as an object of knowledge. Benveniste (1966-1974), still in the field of linguistics, referred to the metalinguistic faculty as a human ability to take a step back from language and to observe it while using it in communication. The term 'metalinguistic' is therefore also associated with the human capacity to see language both as an abstract entity and as an object of discourse.

In the same line of thinking Culioli (1990), puts forward the idea of language activity as an object of linguistics. A linguist's task is to devise a model, a metalinguistic construction, a system representing the language, which does not stand for the empirical data themselves but considers the language as a system of representation. Thus, metalinguistic activity is related to the operations of the individual and not to the communicative functions of the linguistic system. Therefore, we can learn from Culioli that metalinguistic activity does not appear in a unique way, but has different levels: (1) unconscious activity, known as epilinguistic activity; (2) conscious activity, which can be seen, for example, in the control of the use of language; (3) conscious activity verbalised using everyday language; and (4) metalinguistic activity systematically organised into formal models and using technical terms.

The Representational-Redescription model (Karmiloff-Smith, 1986) is one of the most important psycholinguistic models. It distinguishes different types of metalinguistic knowledge according to how they are represented in the human mind (primary, secondary and tertiary implicit and explicit knowledge). It formulates the hypothesis that the step from one level to another goes through the processes of redescribing these representations. Gombert (1990) reformulates Karmiloff-Smith's model, and gives more importance to the contextual factors in the evolution of the way learners represent language. 
Metalinguistic capacity has also been an object of research into second language acquisition and use. Bialystok $(1991,1994)$ states that not all linguistic uses need the same type of representations or knowledge of language, nor do the speakers have the same degree of control for each of the different uses. Two parameters of linguistic use are defined: analysis and control. These parameters are more or less important in every linguistic use, and determine whether attention is focused on form or function, both being complementary activities (Guasch 1995). On the other hand, the concept of collateral sequences (Levelt 1983), whose function is to re-establish the interlocutors' agreement about the code when there is some sort of mismatch in the verbal exchange, also shows the speakers' metalinguistic activity.

We can say that language use has a metalinguistic function. De Pietro, Matthey, and Py (1989) talk about potentially acquisitional sequences when they occur in exolingual dialogues between a competent speaker and a learner (or between learners, Guasch 2001), and they assign them a function in language learning. Metalinguistic knowledge has also been explored in terms of the acquisition of reading skills. For example, Roth et al. refer to 'metalinguistic awareness', which is defined as 'the ability to objectify language and dissect it as an arbitrary linguistic code independent of meaning' $(1996,258)$. They focus their interest on determining the influence of metalinguistic awareness (metasyntax, metamorphology and metasemantics) along with narrative skills in reading, and consider metasyntax as having the most powerful influence.

From a sociocultural point of view, metalinguistic knowledge appears in social interaction (Bronckart 2008; Dolz 2011). It also underlines the determining role of dialogue, which originates and promotes linguistic and metalinguistic activity. Written language becomes a privileged medium for promoting this activity because it entails two operations: (a) the decontextualising of language with respect to the actual communication situation, which means that it can be used as an object of observation and reflection and (b) the progressive organising of the discourse in a process of linguistic contextualisation in order to fulfil its deferred communicative function.

In the field of education, influenced by Chomsky's concept of grammar as an implicit knowledge of all speakers, the term implicit grammar has become widely used to refer to that 'innate' or unconsciously acquired knowledge, as opposed to explicit grammar, acquired as a consequence of having learnt grammar contents. The first of these, 'implicit grammar', would be considered unconscious, and the function of teaching should be to make this grammar emerge, making it explicit by using metalinguistic terms (cf. for example Peytard and Genouvrier 1970 for L1 teaching, and Ellis 1990 for foreign language teaching). We refer to these concepts because they 
have had a widespread influence on teaching even though they only correspond to one of the metalinguistic first levels in the models of Culioli and Karmiloff-Smith. Both authors also talk about grammar models and metalanguage in referring to the higher levels in their models.

We consider that the dichotomy between implicit and explicit grammar is not enough to account for the complexity of the activity that individuals carry out with regard to language. In order to progress in research into grammar teaching, it is necessary to take into consideration the complexity of the metalinguistic activity that emerges from linguistic and psycholinguistic studies. In a grammar teaching model, we consider that we should take into account the diversity of levels and manifestations that this activity has. In schools therefore, a model of grammar teaching should go beyond the general distinction between implicit and explicit grammar so frequently encountered in available pedagogic grammars. Building on the contributions of Culioli (1990) and Karmilof-Smith

(1992), and on the results of research into metalinguistic activity in the writing composition processes (Camps and Milian 2000), we defend the need to establish different levels in which metalinguistic activity manifests itself. Recognising that there is an implicit metalinguistic or epilinguistic activity inherent to language use, we consider that there is a need in schools to focus on explicit metalinguistic activity, i.e. on that activity which is externally manifested. This external manifestation would be threefold (Camps et al. 2000). On a first level, it would be a non-verbal manifestation, which nevertheless can be seen in verbal or procedural activities (reformulations, repetitions, emphasis, etc.). This could be related to the school activity known as 'sentence combining' as well as to many other activities using spontaneous manipulation of language elements, especially in the written mode. Such an activity can be observed in the spontaneous conversation among learners while writing a text collaboratively. This is always the activity that stems from a plethora of language games from the very first years of language development in children. We consider this to be the basis on which a more systematic activity of suppression or addition of elements can be built, along with those activities of change of order, permuting, comparing sentences or texts, etc. These activities will be the basis for a further grammar conceptualisation. We can say that this level of metalinguistic activity does not manifest itself verbally but can be potentially verbalised, in contrast with the first level of Karmiloff-Smith's model and Culioli's definition of epilinguistics.

On a second level, it would be verbalised in everyday language, which can be seen in the spontaneous and informal talk among students about the language they produce or manipulate. The possibility of objectifying procedures, such as the ones we 
have referred to in the first level above, brings with it the necessity to talk about them, to use language to talk about language. At this point, we can talk in terms of 'metalanguage' in the sense referred to by Jakobson and Rey-Debove when they affirm that metalinguistic function of language can also be expressed through the use of common language.

Finally, on a third level, it would be verbalised using a specific metalanguage, which responds to the need to give a name and a conceptual entity to the elements manipulated. It would give rise to the need for the concepts to be systematised in a coherent school grammar model, taking for granted that models do not emerge directly from reality but are instead an interpretation of it. Therefore in the metalinguistic activity undertaken by individuals, it is posible to distinguish three different levels: a procedural and non-verbalised level, a level verbalised in a common language and a systematised verbalised level which is expressed in specific metalanguage. We can call metalinguistic knowledge these three different types of knowledge about language. The interest of the first level lies precisely in the fact that it may manifest itself with no explicit grammar consciousness, yet be the starting point for an eventual guided reflection by teachers. The second and third levels would imply different degrees of awareness about grammar phenomena. In these levels, we find the differences and relationships which several authors recognise between spontaneous and scientific concepts (cf. Cassirer 1944; Vygotsky 1978).

We wish to stress that knowledge about language (i.e. metalinguistic knowledge) should be approached in the same manner in which human conceptualisation is explored, something that has already been done in the study of scientific concepts in other areas of knowledge. By means of language, humans have developed the ability to conceptualise the world, comprising language. When systematising knowledge, science is based on this spontaneous knowledge, yet goes well beyond what is immediate and apparent, and elaborates models that explain reality. The study of those learning about spontaneous concepts demonstrate to what extend these concepts are inadequate. Re-conceptualisation is therefore important. Contrary to what the duality of implicit-explicit knowledge might suggest, the idea that the trajectory from implicit to explicit is a straight and linear one cannot be sustained. Explicit knowledge about language does not consist simply of making explicit that which is implicit. Spontaneous knowledge is a base upon which to build further in-depth knowledge, but systematised models offer perspectives that may occasionally contradict spontaneous perception. What we mean by this is that between both levels implicit and explicit - there is no single direction: at certain school levels, direction will be twofold: from implicit to explicit and the other way around. We also defend the 
notion that this process should be dialectic between the scientific concept and the observable reality of language.

The above underlines the importance that grammar instruction has in school in taking into account the spontaneous concepts learners develop as well as linguistic models that can serve as a reference in school. The objective is to elaborate a model of intervention that allows them to be intertwined and offers the students a basic and stable knowledge of how languages function and of how they can be used.

Two lines of research will bring metalinguistic activity closer to language learning: (1) one which studies metalinguistic activity in writing processes and (2) one which analyses the students' grammar concepts in order to detect obstacles.

\subsection{Metalinguistic activity in writing processes}

Numerous studies have examined metalinguistic activity in relation to writing, from a variety of perspectives. The majority of research has dealt primarily with metalinguistic awareness in early literacy learning and in foreign language learning, limiting what is metalinguistic either to the conscious activity about language or to metalanguage. There is less research into metalinguistic activity in $L 1$ reading and writing processes at higher educational levels. However, it is evident that writing, and especially revising what one writes, always implies some sort of conscious metalinguistic activity. In order to make progress in the research into the relationship between grammar learning and the written use of language, we need to study the metalinguistic activity shown during the writing processes and the metalinguistic activity these processes entail.

In the book edited by Camps and Milian (2000), several different issues are raised, and together these give us a broad view of metalinguistic activity. Some of the more relevant ones are: the role of metalinguistic reflection as a factor in developing writing competence in academic situations (Tolchinsky 2000; Castelló 2000), the influence of social and cultural factors concurring in writing activities (Pittard and Martlew 2000; Dolz and Erard 2000), the relationship between metacognition and metalinguistic activity (Castelló 2000; Rijlaarsdam and Couzin 2000; Allal 2000), and the analysis of metalinguistic activity in collaborative writing processes and the characterisation of the different levels in this activity (Camps et al. 2000). In the framework of the now classical research into written composition processes, various authors have analysed the operations used in writing revisión (Bartlett 1982; Bereiter and Scardamalia 1987). These operations require different levels of metalinguistic activity: (a) perception of the malfunctions in the text leading to the detections of the 
problem; (b) diagnosis, which requires a much more conscious metalinguistic activity; and (c) correction, which requires a command of the alternative syntactic-textual forms and an explicit analytical capacity to consider both the meaning and the linguistic forms which convey it.

Subsequent studies have made progress in characterising metalinguistic activity in the revision processes (Ribas 1997). Camps et al. (2005) analysed interactions among secondary school students during the processes of writing and correcting texts. They confirm that the students reformulate what they have just written or what they propose to write, simply formulating alternatives or reasoning verbally about the new proposals using common language or metalinguistic terms ('intended text', Camps 1994). This student activity has been the basis for teaching proposals which take into consideration this ability as a formative evaluation mechanism which promotes learning (Ribas 1997). More recently, Horning (2006) states that adults experienced in writing texts use three types of awareness in referring either to the text or the discourse: metarhetoric awareness, metastrategic awareness and metalinguistic awareness; i.e. awareness of the linguistic forms from syntactic, lexical and phonological points of view. The author states that experienced students 'know about language, know what they know and what they don't, and pay attention to language per se as they revise' (Horning 2006, 119).

Burkhalter (1996) raises a crucial issue when analysing the relationship between the contents of grammar teaching and metalinguistic activity in the writing process. She summarises both the advantages and limitations found in them, based on the difference between implicit and explicit grammar in Bialystok's model (Bialystok and Hakuta 1985). This study analyses the effect of three types of grammar instruction: traditional grammar, 'sentence combining' and inductive/functional grammar. The overall conclusion is that there is a place for grammar teaching in the classroom but that the methodology needs to be refined. Hence, this study places us at the crossroads between the content of teaching and classroom approaches. In our opinion, it offers a framework in which to consider the relationship between the different levels of metalinguistic activity described in the last section: from an implicit activity based on a procedural type of activity to an explicit and verbalised metalinguistic activity, which allows the text to be operated upon consciously.

\subsection{Students' grammar concepts}

Studies into grammatical concepts show the difficulty students face in constructing coherent grammatical knowledge. Several authors (Carter 1990; Hudson 
2001; Janks 2010) believe that the ability to reflect explicitly on linguistic uses can help us to create an analytical framework in order to improve these same uses (contrary to the conclusions drawn by Andrews, Torgerson, Beverton, Locke et al. 2004; Andrews, Torgerson, Beverton, Freeman et al. 2004). They suggest that there is continuity between intuitions about uses and explicit reflection. There is Little research into learners' concepts in the area of grammar, although in other areas of teaching such as the experimental sciences and mathematics there is a long history of research (Pintó, Aliberas, and Gómez 1996). With regard to linguistic concepts, one of the pioneering studies, Piagetian in origin, was carried out by Ferreiro and Teberosky (1979) and focused on the linguistic concepts related to writing in early school years. Exploration of the grammar concepts at higher school levels is still an underdeveloped area of research. It is descriptive in nature and focused on isolated categories, due to two types of problems: (a) the characteristics of grammar knowledge (which refers to both the implicit knowledge of the speaker and the structured knowledge of the scientific model, with diverse levels between them, and is difficult to systematise) and (b) the lack of consensus, mentioned earlier, about a linguistic model of reference (a reflection of the lack of consensus in the scientific community itself) (Bronckart 1989). In Frenchspeaking, English-speaking or Catalan-speaking areas studies have been carried out into diverse grammar concepts: subject, direct object, aspect, tense, noun, pronoun, adverb or adjective (Boutet, Gauthier, and Saint-Pierre 1985; Brossard and Lambelin 1985; Kilcher-Hagedorn, Othenin-Girard, and de Weck 1987; Fisher 1996, 2004; Martin 1999; Myhill 2000; Camps 2000; Notario 2001; Ribas et al. 2002; Gonzalvo and Camps 2003, etc.).

Guasch (forthcoming) summarises the observations made following two of these studies: that of Myhill (2000) and the one by Fisher (2004). This author considers the coincidences in the appreciation of the difficulties experienced by schoolchildren when building precise and functional grammar notions. These observations coincide with research carried out in the area of Catalan. In a study into grammar teaching in the UK, Myhill collects ethnographic data on 12 year-old students and on trainee teachers which allow her to observe three types of misconceptions in the learners' grammar notions. Fisher, in a reflection on what happens in the French-speaking world, raises the question of the distance between the knowledge taught and that which the students make their own, and she explains this distance based on the obstacles that students have to overcome in order to build new knowledge based on their previous knowledge. Guasch (forthcoming) maintains that there is a correspondence between the misconceptions mentioned by Myhill and the obstacles postulated by Fisher. Firstly, Myhill speaks of the erroneous conceptions acquired in academic life, based on school 
grammars that convey poor definitions of linguistic notions, with simplifications that lead to errors, with atomised contents, and with activities that apply the memorised rules mechanically. These elements constitute methodological obstacles, in Fisher's terminology, to building coherent and functional grammar knowledge. Secondly, Myhill observes the gaps and the inefficiency in certain analytical grammars (descriptive or normative) when certain linguistic phenomena are presented. This observation is congruent with Fisher's observation on the difficulties encountered when tackling certain problems regarding sentence, textual and functional perspectives in school grammar; or with the difficulty in establishing congruent formulations about the interlinguistic variation in the simultaneous teaching of diverse languages (Fisher refers to these obstacles in terms of epistemological obstacles due to the intrinsic complexity of the object of teaching and learning). Thirdly, and lastly, according to Myhill there are erroneous conceptions which can be attributed to the highly abstract nature of metalinguistic activity: the conceptual difficulties coming from the use of the language employed to describe the language itself, for example; or how difficult it is to agree on some prototypes of grammar notions given the linguistic variations. Fisher considers the obstacles in the learners' cognitive sufficiency as psychogenetic obstacles.

To sum up, according to these authors, interventions for teaching reflection on grammar in the classroom have to be configured with great attention to classroom approaches themselves, to the control of the intrinsic complexity of the grammar phenomena in question, and to the cognitive capacity of the students at different levels. Coinciding with the observations made by Myhill (2000) and Fisher (2004), Camps (2010) underlines the need to explore the problems related to the structure of the grammatical knowledge itself. She indicates three levels of gramatical obstacles from an epistemological point of view. The first level would be the separation between sentence and discourse, referring to Charolles and Combettes (2001) on the tradition of studies into text and discourse and the diverging directions they take throughout history. This fact makes it impossible for pedagogical grammar to refer to a coherent theoretical framework. A second level would be the complexity, both for learners and teachers, of the plurifunctionality of the grammatical forms. An example of this, according to Camps, is the pronoun, which has specific functions in discourse, in the text, and in the sentence. Agreeing with Barth (2007), the difficulty would be in the structure of the knowledge itself. Finally, the third level would be the early or spontaneous grammatical knowledge, which can be an obstacle to the progressive learning of more complex aspects. Bachelard (1987), in his research into mathematical learning, considers this sort of obstacle an 'epistemological problem'. It deals with the problems arising from the necessary temporary sequencing of the appearance of 
interrelated concepts. Studies provide three examples concerning this issue: the definition of the verb as an action, the definition of an adjective as an attributive quality of a noun or the concept of gramatical person. The lack of evolution in these concepts throughout schooling leads one to believe that the student needs to be accompanied in the processes of abstraction (Barth 2007), an area which has been explored extensively in mathematics (Sfard 2000; Schwartz, Dreyfus, and Hershkowitz 2009).

\section{The aim of teaching grammar}

Before dealing with the relationship between learning grammar and learning how to use language, it is necessary to address the following question: What is the aim of teaching grammar? It is not easy to answer this question, posed in the previous section. The grammar which emerged from the classic studies of language gave rise to the categorisation of grammar concepts which has been maintained for centuries with few modifications (Baratin 1989; Auroux 1989). 'Traditional grammar', as it later became known, was born out of two basic needs: language teaching (Greek to those who did not know it) and the interpretation of classical authors. When these concepts were introduced into schools and teaching became more general, the school routines themselves became the content of teaching and learning and as a result lost most of their purpose.

The linguistic revolution which took place in the first half of the twentieth century had a profound effect on the process of redefining school grammar, and was focused on rationalising it and adapting it to a more scientific approach. Saussure and Chomsky's contributions, from different theoretical perspectives, used scientific reductionism in their linguistic studies and established a homogeneous field of research (social: langue; or individual: competence), leaving out the aspects which relate language to its environment3. A number of school adaptations arose from these theoretical ideas (Bastuji 1982), some of which had a huge influence on their linguistic contexts. Here are two examples: the structural position put forward by Manacorda de Rossetti (1964), who has been a widespread influence in schools in Argentina since the 1960s more or less up to the present day; and that of the aforementioned Dubois, the generative position, which became widespread in France from the 80 s onwards. It is also fair to say that both these basic models, the structural and the generative, have made interesting contributions to teaching, yet they cannot be assimilated as a whole at school. The reason behind this is that scientific theories need to be adapted when the purpose is to teach them in the school setting, since the aims of linguistic science are different to those of schools 
The implementation of these theories in schools made the gap between school grammar and language use even greater. The concepts of structuralism and generativism have subsequently been questioned from a functional perspective, which has stressed particularly the incapacity to explore the three-way relationship between cognition, social interaction and the nature of language. This is especially evident in the case of the generative postulates because of their interest in what is known as the faculty of language' (Tomasello 1995; Ellis 2003). This is the only faculty which would be a real entity in generative theory, which considers that languages as they are used are simply epiphenomena of no relevance to language theory (Bernárdez, 2008). The irrefutable progress in the analytical description of the system, and the fact that it has been possible to adopt a formal perspective for studying languages, has brought generative linguistics closer to what was at one time considered the science of its time, physics, and this was considered of great importance in an emerging discipline. However, the formal models are opposed to the functional models of authors such as Bühler, Lyons, Jakobson, Sabatini, Schmidt, Halliday or Adam (González Nieto 2001), who are interested in exploring language from a communicative perspective.

Bernárdez (2001) proposes a metaphor of language, incompatible with the generative postulates: 'A language is a complex, self-regulated organism'. Moreover, as it does not have an innate root, language would be a system of interactive systems between individuals, where regularities would organise their apparently chaotic behaviour in a way that could be described and accounted for with notions from diverse fields such as sociology (habitus), neurology (synapses and experience), mathematics (the theory of complexity), sociocultural psychology (interaction with the social environment) or biology (organism). These notions thereby support the epistemological viability of language theory from languages as they are used, with reasons which lead one to believe, as Bernárdez points out (2001), that in fact the actual epiphenomenon is the so-called 'language faculty'. Ellis (2003) calls studies which share this vision 'constructivisms', which would all have in common the fact that they conceive language in terms of processes and relationships and not in terms of objects and final states. Among these studies, we find the study on corpus (O'Keeffe, McCarthy, and Carter 2007), emergentism (Helasvuo 2009), the theory of complexity (Finch 2001; LarsenFreeman 2003), functional linguistics (Halliday and Webster 2007) or the ecologicsemiotic perspective of language (van Lier 2008).

For Weigand (2011), these more holistic visions overcome scientific reductionism and are open to what is heterogeneous and related to the functional dimension, and this is beneficial from the point of view of education, especially with regard to teaching grammar. Several authors, from a variety of perspectives 
(Rutherford 1987; Richmond 1990; Long 1991; van Lier 1995; Pennington 2002; Larsen-Freeman 2003), look for ways to develop teaching models which allow for the re-dimensioning of the term 'grammar' and for it to be conceived as an organic unit of uses, meanings and forms. These three aspects have been often explored separately: pragmatics has studied the communicative uses of language systematically, semantics has focused on meanings and morphosyntax has analysed the formal aspects. We mentioned Charolles and Combettes (2001), who echo the schism in the field of linguistic research, which, as we have already said, dates right back to the classic era and is reproduced in the classroom. While the emphasis in schools for a grammar system is placed on the non-functional side, the functional approaches coming mainly from rhetoric have a great influence on the way writing is taught.

Moreover, as Camps et al. (2005) indicate, these two different approaches gave rise to two different teaching practises in the classroom: transmissive methodology in the former and constructivist in the latter. This disjunction has yet to be overcome, and there is an urgent need for grammar models for schools which simultaneously take into consideration the morphosyntactic, semantic and pragmatic aspects of linguistic forms, in order to bring students closer to language in use. Many of the studies undertaken into the influence of grammar on learning the written use of language o not find the notion of 'grammar' problematic, although, as we have just seen, it is very diverse and highly problematic. The majority of researchers attempting to explore the relationship between grammar knowledge and writing do not define very clearly what object they are referring to when they are talking about grammar nor from which perspective it is being examined. One example of this is the aforementioned studies carried out by Andrews, Torgerson, Beverton, Locke et al. (2004) and Andrews, Torgerson, Beverton, Freeman et al. (2004), who use the term 'grammar' with very generic adjectives (some of them being presented at some point as synonyms) such as 'formal', 'traditional', 'decontextualised' or 'generative'. The authors do not question whether the conception of the teaching object is relevant in grammar teaching or if it affects learning written composition. According to Locke (2009), these studies seem to want to precipitate the closing of this debate. The author gives as an example the careful study by Elley et al. (1978, quoted by Locke 2009, 183) focusing on the Oregon curriculum.

These authors state that the effects on the writing style or the transformations made in the writing process are exactly the same, whether the students are taught generative or traditional grammar or if they are taught no grammar at all. Posing questions about what we teach when we teach grammar can help in showing the lack of consensus on which linguistic knowledge should be used as a reference in schools (Bronckart 2008; Locke 2010). A lack of consensus in turn reflects the lack of a 
common framework in linguistic research. In this sense, many authors have expressed the need to address the didactic transposition processes, in the same way as Chevallard (1991) did with mathematics. The concept of 'pedagogical grammar' is gaining ground, especially for second language acquisition (Walmsley 1997), yet the need for a coherent corpus of grammar knowledge has also been underlined for first language acquisition. Pennington (2002), for example, in synthesising the notions of traditional and modern linguistics, proposes a grammar model for school with four attributes: (a) collocational: which focuses on the semantic structures of words and the connection between words and discourse and not on the abstract levels of the syntactic structure; (b) constructive: conceptualising communication as a continually evolving process, built from elements which are constantly being added to a sequence to form a speech chain; (c) contextual: relating syntactical and lexical choices to communicative aims as well as to the purpose of the discourse and the negotiation of the meaning; and (d) contrastive: interested in the possibilities of building bridges between the languages that the students already know and the new languages they are learning.

Therefore, a whole range of approaches has come to light regarding what we call grammar in primary and secondary schools, as well as several open debates about what the implications will be for education. If the aim of education is the language system, what are the units: the word, the sentence, the text? What theory are we using to address them? If the aim is language in use, how can we account for what is dynamic and diverse? Should we organise, in a coherent system and through a process of abstraction, the host of observations about language in use? Moreover, is it possible to have a pedagogical grammar which organises the grammar content systematically and which could be used as a toolfor learning language use? From this perspective, there is no point in talking about 'decontextualised grammar' as a synonym for 'grammar' from a school perspective.

Is it possible that a change in grammar content and the concept of grammar itself could influence writing capacity in a different way? Our hypothesis is based on the fact that the way we conceptualise research into teaching grammar will have an effect on the effectiveness of teaching, especially taking into account that reconsidering the object leads to reconsidering the educational methodology.

\section{Classroom approaches}

As well as considering the aim of grammar teaching and the characteristics of the knowledge of those who are learning, we also need to pose questions with regard to the learning and teaching processes, which would allow grammatical knowledge and 
written use to be related. It is especially important to raise questions about the characteristics of interaction in the classroom in order to allow for the coming and going processes between use and abstraction. It is necessary to re-conceptualise what is understood by scaffolding and to question the helping mechanisms that the teacher can apply in order to create the 'zone of proximal development' which allows the students to make progress both in learning the concepts and in verbal uses. The hypothesis which could be supported is that a change in the teaching ofgrammar content (which overcomes an exclusively formal approach and which takes into account the formal, semantic and pragmatic components of grammar) will help to overcome the transmissive approach. We need to redirect action in the classroom towards practices that implicate students in the practice of observing and manipulating linguistic forms in order to reach abstract knowledge.

With regard to practices developed in the classroom, we adopt a sociocultural perspective, according to which a transmissive teaching and learning methodology focused on the teacher's discourse will make it difficult to conceptualise language as a cultural, dynamic object and related to speakers' practises (Bain, Fitzgerald, and Taylor 1992; Wells 1999). The research into students' grammar concepts we mentioned earlier suggests that in language teaching (and especially regarding the teaching of grammar) it is necessary to have a methodology that goes beyond mere direct instruction. In this sense, the methodology in the classroom belongs to teaching content (Bergin 1999). Edwards and Mercer (1987) underline the need to create contexts within the classroom which allow the learners to build a 'principle-based knowledge' which goes further than 'ritual knowledge'. 'Ritual knowledge' is related to the context of explanations given, and as a result it is very difficult to use in other situations, whereas principle-based knowledge is more generalised and can be transferred to other situations (Bruner 1986).

The whole support process would be based on contingency resources, gradually removing support and transferring responsibility, and finally promoting selfsufficiency (Wood, Bruner, and Ross 1976; Cazden 1979; Tharp and Gallimore 1988; Hung 1999). It would be articulated at several levels while acknowledging the fact that education is not the accomplishment of a previously limited and content-oriented script, which justifies it, but a process of internal reconstruction with external help, with the objective of attaining individual self-sufficiency. Some studies place this process within the framework of local intervention by a teacher or classmate, leaving aside the general framework and in terms of direct instruction (see an example of this in van de Pol, Volman, and Beishuizen 2011). In this way, we need to re-conceptualise what we understand by support, and ask ourselves about the helping mechanisms the teacher 
can employ to create a zone of proximal development that allows students to make progress both in learning the concepts and using the language. Hence, van Lier (2004) establishes four types of support: someone who knows more helps us, we help people who know less, equal partners help each other or we use the provided resources. In broader terms, Piggot and Barr (2002) conceptualise support as the influx which the established mechanisms exercise indirectly on the learner at a macro level. Many studies have explored the macro-micro relationship (Granott 2005; Mascolo 2005; Anghileri 2006). They develop models with three different levels: a general level, which relates to the organisation of the intervention; an intermediate level, which relates to the programmed activities according to the initial question and the final objective and a third level, related to local interactions. From this perspective, the classroom would be understood as being a kind of learning community (Wenger 2009), with multiple situations and affordances for learning (van Lier 2004), following intervention models combining macro (global design) and micro levels (local interaction). Hakkarainen and Paavola (2009) propose the so-called trialogical inquiry model (agent, learning objective and mediator), designed to create knowledge, which goes further than the two normal forms of accessing knowledge (participation and acquisition) proposed by Sfard (1998).

\subsection{Interaction in the classroom}

Within the framework of learning grammar, what characteristics are essential in the interaction in the classroom in order to facilitate the process of relating verbal use and abstraction? Some of the already mentioned research studies into grammar learning have already tried to answer this question and have underlined the fact that the interviewed students themselves realised that the fact that they had spoken to the interviewer-researcher helped them to reflect on metalinguistics. This leads us to believe that concepts emerge through conversation, and that this could be the basis on which to build more elaborate knowledge. As has already been observed in areas such as mathematics, science, social science or art, classroom interaction enhances learning. This suggests the need to explore how promoting classroom interaction may enhance the construction of grammar knowledge.

Mercer $(2000,2008)$ considers working on the basic rules of exploratory talk in the classroom to be crucial. It acts as a framework within which social interaction leads to the building of shared knowledge. Studies into exploratory talk (Mercer and Littleton 2007) suggest that working in small groups will only lead to the creation of significant knowledge if the learners are capable of self-regulation and of generating their own 
arguments from a shared common space. Fernández et al. (2001) call it IDZ 'intermental development zone', and conceive it as the common space where the processes of support and learning occur. Lampert (1992, quoted by Wells 1999, 159) describes the type of language which is produced there as 'disorganised' and Paavola and Hakkarainen (2005) speak of 'creative chaos rather tan pre-structured and strictly controlled instructional processes'. Other characterisations of classroom talk as intellectually stimulating, collaborative and productive would be collaborative reasoning (Chinn and Anderson 1998), accountable talk (Resnick 1999; Michaels et al. 2002), critical discussion, explanatory enquiry, heuristic discussion and consensus dialogue (Keefer, Zeitz, and Resnick 2000) or productive dialogue (Wegerif et al. 2009).

A quick review of research into classroom interaction (Tsui 1997; Cubero 2005), shows a shift from focusing exclusively on the teacher's discourse (in order to find the 'best method' of interacting with the students so that they learn) to studies into students' discourse and student-teacher interaction, alternating between a macro and micro perspective. They point to the need for a participative methodology, based on dialogue and collaborative inquiry (Wegerif, Mercer, and Dawes 1999; Cubero et al. 2008). This is also valid for teaching grammar. The studies edited by Ribas, Fontich, and Guasch (Forthcoming) suggest that this is also valid for teaching grammar. These studies reveal new insights about the complexity of classroom interaction while learning grammar, and consider that this is an area in which the influence of collaborative stages on building knowledge has not yet been fully explored.

\subsection{The pedagogical system}

The different proposals for innovation in grammar teaching all agree that the problem lies in the relationship between teaching activities, learning activities and the teaching and learning contents. Therefore, they locate the problem in the relationship between the different poles of the pedagogic system: teaching, learning and content (Chevallard 1991; Bronckart and Schneuwly 1991; Locke 2010). As far back as 1958, in a pioneering study focusing on written composition, the psycholinguist J. B. Carroll (quoted by Hudson 2001, 6) referred to those studies which denied any influence of grammar teaching on writing, and he drew attention to the need to respond to these studies with interventions which contemplated new forms and methods in the classroom. These interventions would have to pay special attention to developing activities which allow the learners to participate together in heterogeneous groups, with the teacher's flexible guidance. This is the same position held by Carter (1990), or the proposals put forward by Bain et al. (1992). These authors defend the benefits for 
students of a participative methodology based on shared reflection throughout the writing process as well as on what is produced, and on the fact that the students' attention is explicitly directed to specific grammar notions and to the effect they could have on different types of texts. In the English-speaking world, examples of this are the proposals by Janks (2010), Freeman and Freeman (1998) or Myhill et al. (2012), and in the French-speaking world those of Clauzard (2008) or Paolacci and Debanc (2009).

In the Catalan context, some of the proposals along these lines are those by Milian and Camps (2006), Fontich (2006) and Guasch (Forthcoming). They are focused on studying exploratory talk triggered in grammar lessons that have been organised by following the so-called GDS model (Didactic Grammar Sequence). They show the significant potential of a participative scenario as well as its problems. Milian and Camps show how students working together in a large group on diverse aspects of grammar (sentence, connectors and verbal correlation), even with the teacher's help in creating an exploratory, collaborative and contingent atmosphere in the classroom, still have low levels of abstraction. The authors underline, however, that it is precisely in this open and contingent interaction that these problems arise, and that the micro situations analysed suggest the need to expand and accompany these discovery processes. Fontich designs a sequence of activities to promote the construction of grammar knowledge throughout the interaction in the classroom. He shows that, when the students are aware of the importance of cooperation, they are much more capable of helping one another and of integrating more grammar notions into speech in order to solve the problem at hand. Guasch points to the need for exchange in the classroom between the small groups of students and the teacher, while underlining the danger if the teacher's speech and that of the students fail to coincide.

\section{Conclusion: the basis for a grammar teaching model which allows for reflection and relates abstraction and use}

The debate on the influence of grammar teaching in learning to write has been considered from a very general perspective, without really looking at aspects we consider to be crucial regarding a conscious and reflective language teaching. We shall deal with these aspects in the following three sections, according to our initial questions: the content of grammar teaching (meaning the grammar taught in schools), the students' capacity to consider language as an object to talk about (meaning metalinguistic capacity) and lastly, the methodology (which has to allow the conscious relationship between linguistic forms and language use, especially written use). Some basic trends and issues arise from these three main sections, and these must be taken 
into account when considering a grammar teaching which relates to language use activities and contributes to improving it. We have summarised these basic trains of thought into ten key points, presented under three headings.

\subsection{On metalinguistic activity}

Language develops alongside metalinguistic activity development. It is necessary for teaching to take into account the human capacity to conceptualise language as an object to be manipulated, observed and considered. Children acquire this object naturally and the school has to help to develop it in order to promote conscious and critical language use. Furthermore, in order to re-conceptualise grammar teaching it is important to understand that metalinguistic activity can be found in many different forms in the use and learning of first and second languages. It can be seen in the way we transform language while we use it to communicate with others; it can also be expressed through a common language or even in a specialised metalanguage. Lastly, activities carried out at an operational level, such as combining sentences, substitutions, changing word order, etc. must be the basis for those activities which require explicit verbal reflection in common language and in order to gradually introduce the necessary and useful metalanguage at every teaching level. If the grammar teaching is to be significant and recoverable, the notions and concepts must be interrelated and we must avoid presenting them in an atomised and sporadic manner.

\subsection{On the content}

If in education, grammar is to be a tool for reflecting on language use, especially written language, then theoretical reference models are necessary, where the linguistic forms can be contemplated from the perspective of words, sentences and discourse. We therefore have to place ourselves in the framework of functional models and take into account the morphosyntactic, semantic and pragmatic perspectives.

Next, the teaching process needs the theoretical grammar models to be adapted to this function. Hence, we need to create what has been called pedagogical grammar. That is to say, we need to choose the concepts in such a way that they constitute an adequate teaching system and a set of procedures which the students can make their own. A Pedagogical grammar is therefore the corpus of systematic concepts and procedures considered adequate for teaching. Lastly, the teaching process requires sequencing; it is also a dynamic process, which means that it is 
necessary to take into account the processes we have used to adapt the chosen concepts to each level and to each situation, so that they will be learnt; this corresponds to the so-called didactic transposition, which is also known as didactic adequacy.

\subsection{On classroom approaches}

The objectives and content of grammar learning have to form the basis of an integrated work, and the students must be familiar with these objectives. Formulating the learning units as work projects or research projects could be a suitable way of making sense of grammar work. Complex grammar teaching sequences allow the different work modalities to be combined: collectively, in groups, and individually. Secondly, the teacher must be ready to help in developing the work projects at all levels: the process of organising the project itself will be the initial framework which allows the students to work in a format that makes sense of the operations and tasks they are carrying out. The teacher's help in groups or individually always refers back to the shared overall objectives and helps in accomplishing the task being carried out. Next, the interaction between the teacher and the students is the basis for a shared reflection. The structurally complex units allow this interaction to occur in all directions, as well as being the way in which the teacher detects conceptualisation problems and helps the students to solve them. Lastly, there are two main starting points for relating grammar content and discursive production: we can start with the text and focus on a problem we detect, or we can start with the grammar content in order to analyse how certain forms behave in texts.

By grouping these basic trains of thoughts into three sections in order to progress in grammar teaching research, our aim has been to underline the need to make the pedagogical system the focus of the research. We consider that, from a research perspective, a good knowledge of a complex object (as is the case of grammar teaching and learning related to language use) should take this fact into account.

\section{Acknowledgements}

We extend our thanks to Teresa Ribas, Oriol Guasch and Marta Milian for very helpful comments on previous drafts of this paper. We are also very grateful to the anonymous reviewers for their encouraging and constructive comments.

\section{Notes}


1. Spain is politically and administratively divided into 17 regions or Autonomous Communities (plus two autonomous cities) which have autonomy in certain areas such as education.

2. Notably the Grup de Recerca sobre Ensenyament i Aprenentatge de Llengües; Research Group on Language Teaching and Learning (GREAL) group in Barcelona (Spain) and the group for educational reform in Valencia (Spain).

3. Both authors focus their study on the systematic aspects of the language. While Saussure adopts a social perspective and focuses on the so-called 'langue', Chomsky adopts a cognitive perspective and focuses on what he calls 'competence'. This means that the aspects that relate language to its environment (what Saussure calls 'parole' and Chomsky calls 'performance') are not considered as being of interest for linguistic research.

4. The process of adapting scientific theories to schools has been the object of an important debate, especially in the French context, although one in which we cannot enter now. See for details Chevallard (1991), Schneuwly (1995), Halté (1998), Bronckart and Plazaola Giger (1998), and Vargas (2004).

\section{Notes on contributors}

Xavier Fontich is an assistant lecturer at the Universitat Autònoma de Barcelona. He has written a number of papers on language and literature teaching, for some of which he has received awards. His doctoral dissertation focuses on the teaching and learning of grammar, and in it he has developed a model which analyses how the metalinguistic knowledge of students is transformed through interaction in small groups in the classroom through interaction.

Anna Camps is a senior lecturer in Language Learning at the Universitat Autònoma de Barcelona. She has carried out many research projects on teaching written composition, on the metalinguistic activity of pupils and on grammar teaching. She has published research on language education as well as on language teacher training on these subjects.

\section{References}

Allal, L. 2000. "Metacognitive Regulation of Writing in the Classroom." In Metalinguistic Activity in Learning to Write, edited by A. Camps and M. Milian, 145-166. Amsterdam: Amsterdam University Press.

Andrews, R. 2010. "Teaching Sentence-level Grammar for Writing: The Evidence so Far." In Beyond the Grammar Wars. A Resource for Teachers and Students on Developing Language Knowledge in the English/Literacy Classroom, edited by T. Locke, 91-108. New York: Routledge.

Andrews, Richard, Carole Torgerson, Sue Beverton, Terry Locke, Graham Low, Alison Robinson, and Die Zhu. 2004. The Effect of Grammar Teaching (Syntax) in English on 5 to 16 Year Olds' Accuracy and Quality in Written Composition. London: EPPI-Centre,

Social Science Research Unit, Institute of Education. Accessed September 23, 2012. http://eppi.ioe.ac.uk/eppiwebcontent/reel/review groups/english/eng rv6/eng rv 6.pdf

Andrews, Richard, Carole Torgerson, Sue Beverton, Allison Freeman, Terry Locke, Graham Low, Alison Robinson, and Die Zhu. 2004. The Effect of Grammar Teaching (Sentence Combining) in English on 5 to 16 Year Olds' Accuracy and Quality in Written Composition: Review Summary. York: University of York. Accessed September 23, 2012. http://eppi.ioe.ac.uk/cms/LinkClick.aspx?fileticket=MJ77C3ymu A\%3dandtabid $=231$ andmid $=1032$

Anghileri, J. 2006. "Scaffolding Practices that Enhance Mathematics Learning." Journal of Mathematics Teacher Education 9: 33-52. doi: 10.1007/s10857-006-9005-9. 
Auroux, S., (Dir.) 1989. Histoire des idées linguistiques [A History of Ideas in Linguistics]. Liège: Pierre Mardaga.

Bachelard, G. 1987. La formación del espíritu científico [The Formation of Scientific Attitude]. México: Editorial Siglo XXI.

Bain, D., and S. Canelas-Trevisi. 2009. "Utilisation de la grammaire scolaire pour le texte argumentatif. Circulation entre deux domaines de la discipline français [The use of a Pedagogical Grammar for Argumentative text. Links Between Two Domains in the Discipline of French Language]." In Des objets enseignés en classe de français [On Taught Objects in the Classroom of French Language], edited by B. Schneuwly and J. Dolz, 231-265. Rennes: Presses Universitaires de Rennes.

Bain, R., B. Fitzgerald, and M. Taylor. 1992. Looking into Language: Classroom Approaches to Knowledge about Language. London: Hodder and Stoughton.

Baratin, M. 1989. "La maturation des analyses grammaticales et dialectiques [A History of Ideas in Linguistics. Maturation of Grammatical and Dialectic Analysis]." In Histoire des idées linguistiques [A History of Ideas in Linguistics], Vol. 1, edited by dir. S. Auroux, 186-206. Liège-Bruxelles: Pierre Mardaga.

Barth, B.-M. 2007. L'apprentissage de l'abstraction [The Learning of Abstraction]. Paris: Retz.

Bartlett, E. J. 1982. "Learning to Revise: Some Component Processes." In What Writers Know, edited by M. Nystrand, 345-363. New York: Academic Press.

Bastuji, J. 1982. "La grammaire générative et transformationelle: sur quelques modes de transmission et de remploi dans l'institution universitaire et scolaire française [Transformational-Generative Grammar: On some Modes of Transmission and Re-use within French University and School Institutions]." Langue Française 53: 78-91.

Benveniste, É. 1966-1974. Problèmes de linguistique générale 1 and 2 [Problems in General Linguistics 1 and 2]. Paris: Gallimard.

Bereiter, C., and M. Scardamalia. 1987. The Psychology of Written Composition. Hillsdale, NJ: Erlbaum.

Bergin, D. 1999. "Influences on Classroom Interest." Educational Psychologist 34 (2):

87-98. doi: 10.1207/s15326985ep3402_2.

Bernárdez, E. 2001. De monoide a especie biológica: aventuras y desventuras del concepto de lengua [From Monoid to Biological Species: Adventures and Disadventures of the Concept of Language]. CLAC-Círculo de lingüística aplicada a la comunicación. Accessed September 23, 2012. http://www.ucm.es/info/circulo/no7/bernardez.htm

Bernárdez, E. 2008. El lenguaje como cultura [Language as Culture]. Madrid: Alianza.

Bialystok, E. 1991. "Metalinguistic Dimensions of Bilingual Language Proficiency." In Language Processing in Bilingual Children, edited by E. Bialystock, 113-140. Cambridge: Cambridge University Press.

Bialystok, E. 1994. "Analysis and Control in the Development of Second Language Proficiency." Studies in Second Language Acquisition 16: 157-168. doi: 10.1017/S0272263100012857.

Bialystok, E., and K. Hakuta. 1985. In Other Words. New York: Basic Books.

Boutet, J., F. Gauthier, and M. Saint-Pierre. 1985. "Activité et discours métalinguistique d'enfants de 6 à 12 ans, en dehors de la classe de grammaire [Metalinguistic Activity and Discourse in 6-12 Year Old Children, out of the Grammar Classroom]." Revue Française de Pédagogie 71: 13-16.

Bronckart, J. P. 1989. "Du statut des didactiques des matières scolaires [On the Pedagogical Status of School Subjects]." Langue française 82: 53-66.

Bronckart, J. P. 2008. "La actividad verbal, las alenguas y la lengua; reflexiones teóricas y didácticas [Verbal Activity, Languages, and the Language: Theoretical and Pedagogical Reflections]." In Miradas y voces. Investigación sobre la educación lingüística y literaria en entornos plurilingües [Glipmses and 
Voices. Research on Linguistic Education in Plurilingual Contexts], edited by coords. A. Camps and M. Milian, 27-44. Barcelona: Graó.

Bronckart, J. P., and I. Plazaola Giger. 1998. "La transposition didactique. Histoire et perspectives d'une problématique fondatrice [Didactic Transposition. History and Perspectives of a Foundational Problem]." Pratiques 97-98: 35-58.

Bronckart, J. P., and B. Schneuwly. 1991. "La didactique de la langue maternelle. L'émergence d'une utopie indispensable [Pedagogy of Mother Tongue. The Emergence of a Necessary Utopia]." Éducation et Recherche 13: 8-26.

Brossard, M., and G. Lambelin. 1985. "Problèmes posés par l'acquisition de quelques notions grammaticales [Emerging Problems in the Acquisition of some Grammar Notions]." Revue Française de Pédagogie 71: 23-28.

Bruner, J. 1986. Actual Minds, Possible Worlds. Cambridge, MA: Harvard University Press.

Burkhalter, N. 1996. "Assessing Grammar Teaching Methods Using a Metacognitive Framework." Journal of Teaching Writing 15 (2): 259-283.

Cameron, D. 1995. Verbal Hygiene. London: Routledge.

Camps, A. 1986. La gramàtica a l'escola bàsica, entre els 5 i els 10 anys [Grammar in Basic School, between 5 and 10 Years of Age]. Barcelona: Barcanova.

Camps, A. 1994. L'ensenyament de la composició escrita [Teaching written Composition]. Barcelona: Barcanova.

Camps, A. 1998. "L'ensenyament de la gramàtica [Teaching Grammar]." In L'ensenyament i l'aprenentatge de la llengua i la literatura en l'educació secundària, [Learning and Instruction of Language and Literature in Secondary School], edited by coords A. Camps and T. Colomer, 105-126. Barcelona: ICEUB/Horsori.

Camps, A. 2000. "El coneixement gramatical dels alumnes: el cas dels pronoms personals [Students Grammar Knowledge: The Case of Personal Pronouns]." In La terminología lingüística en l'ensenyament secundari. Propostes pràctiques [Linguistic Terminology in Secondary School. Practical Issues], edited by J. Macià and J. Solà, 121-136. Barcelona: Graó.

Camps, A. 2010. "Hablar y reflexionar sobre la lengua: hacia un modelo de enseñanza de la gramática basado en la actividad reflexiva en colaboración [Talking and Reflecting on Language: Towards a Model of Teaching Grammar Based on Reflective Activity in Collaboration]." In Libros de texto y enseñanza de la gramática, [Text Books and Grammar Teaching]. edited by coord T. Ribas, 1331. Barcelona: Graó.

Camps, Anna, Oriol Guasch, Marta Milian, and Teresa Ribas. 2000. "Metalinguistic Activity: The Link between Writing and Learning to Write." In Metalinguistic Activity in Learning to Write, edited by A. Camps and M. Milian, 103-124. Amsterdam: Amsterdam University Press.

Camps, A., and M. Milian, eds. 2000. Metalinguistic Activity in Learning to Write. Amsterdam: Amsterdam University Press.

Camps, Anna, Oriol Guasch, Marta Milian, and Teresa Ribas. 2005. Bases per a l'ensenyament de la gramàtica [Basic Issues for Grammar Teaching]. Barcelona: Graó.

Carter, R., ed. 1990. Knowledge About Language and the Curriculum: The LINC Reader. London: Hodder and Stoughton.

Cassirer, E. 1944. Essay of Man. New Haven, CT: Yale University Press.

Castelló, M. 2000. "Students' Conceptions on Academic Writing." In Metalinguistic Activity in Learning to Write, edited by A. Camps and M. Milian, 49-78. Amsterdam: Amsterdam University Press.

Cazden, C. 1979. "Peekaboo as an Instructional Model: Discourse Development at Home and at School." Stanford Papers and Reports in Child Language Development 17: 1-19. 
Charaudeau, P. 2009. "Dis-moi quel est ton corpus, je te dirai quelle est ta problématique [Tell me What your Corpus is, and I will tell you What your Problems are]." Corpus 8: 37-66. Accessed September 23, 2012. http://corpus.revues.org/index1674.html

Charolles, M., and B. Combettes. 2001. "De la phrase au discours: rupture et continuité

[From Sentence to Discourse: Rupture and Continuity]." In Quelles grammaires enseigner à l'école et au collège? [Which Grammar Teach in Primary and Secondary School?], coords, edited by C. Garcia-Debanc, J. P. Confais, and M. Grandaty, 117-141. Toulouse: Delagrave/CDR Midi-Pyrénées.

Chevallard, Y. 1991. La transposition didactique. Du savoir savant au savoir enseigné [Didactic Transposition. From Scientific Knowledge to Taught Knowledge]. Grenoble: La Pensée. Sauvage.

Chinn, C. A., and R. C. Anderson. 1998. "The Structure of Discussions that Promote Reasoning." Teachers College Record 100: 315-368.

Clauzard, P. 2008. La médiation grammaticale en école élémentaire [Grammar Mediation in Primary School]. Paris: CNAM.

Combettes, B. 2009. "Quelle(s) description(s) grammaticale(s) pour l'enseignement? [Which Grammar Description(s) for Teaching?]" Repères 39: 41-56.

Cubero, R. 2005. Perspectivas constructivistas. La intersección entre el significado, la interacción y el discurso [Constructivist Perspectives. Intersection between Meaning, Interaction, and Discourse]. Barcelona: Graó.

Cubero, Rosario, Mercedes Cubero, Andrés Santamaría, Manuel L. de la Mata, María J. Ignacio, and María del M. Prados. 2008. La educación a través de su discurso. Prácticas educativas y construcción discursiva del conocimiento en el aula [Education Through Discourse. Educational Practice and Discursive Knowledge Construction in the Classroom]. Revista de educación 346: 71-104. $\begin{array}{lll}\text { Accessed } & \text { September } 2012 .\end{array}$ http://www.revistaeducacion.mec.es/re346/re346 03.pdf

Culioli, A. 1990. Pour une linguistique de l'énonciation. Vol I [Towards a Linguistics of Enunciation. Vol I]. Paris: Ophrys.

De Pietro, J-F., M. Matthey, and B. Py. 1989. "Acquisition et contrat didactique: les séquences potentiellement acquisitionnelles de la conversation exolingue [Language Acquisition and Pedagogical Contract: Potentially Acquisitional Sequences in Exolingual Conversations]." In Actes du 3ème Colloque Régional de Linguistique [Proceedings of the 3rd Regional Linguistics Colloquium], edited by D. Weil and H. Fugier, 99-124. Strasbourg: Université des Sciences Humaines et Université Louis Pasteur.

Dolz, J. 2011. "Describir la actividad docente: un punto de vista didáctico para comprender el trabajo del profesor en el aula [Describing Teaching Activity: A Pedagogical Point of View to Understand Teacher's Activity in the Classroom]." In L'activitat docent. Intervenció, innovació, investigació [Teaching Activity. Intervention, Innovation, and Research], edited by J. Vallès, D. Álvarez, and R. Rickenmann, 97-114. Girona: Documenta Universitaria.

Dolz, J., S. Erard, and S. 2000. "Metaverbal Activities as an Approach to Teach Spoken and Written Genres." In Metalinguistic Activity in Learning to Write, edited by A. Camps and M. Milian, 125-144. Amsterdam: Amsterdam University Press.

Dubois, J. 1969. Grammaire structurale du français: la phrase et les transformations [A Structural Grammar of French: Sentence and Transformations]. Paris: Larousse.

Edwards, D., and N. Mercer. 1987. Common Knowledge: The Development of Understanding in the Classroom. London: Routledge.

Ellis, R. 1990. Instructed Second Language Acquisition. Oxford: Basil Blackwell.

Ellis, N. 1998. "Emergentism, Connectionism and Language Learning." Language Learning 48 (4): 631-664. doi: 10.1111/0023-8333.00063. 
Ellis, N. 2003. "Constructions, Chunking, and Connectionism: The Emergence of Second Language Structure." In The handbook of Second Language Acquisition, edited by C. Doughty and M. Long, 63-103. Malden: Blackwell.

Fernández, Manuel, Rupert Wegeriff, Neil Mercer, and Sylvia Rojas-Drummond. 2001. "Reconceptualizing Scaffolding and the Zone of Proximal Development in the Context of Symmetrical Collaborative Learning." Journal of Classroom Interaction 36 (2): 40-54.

Ferreiro, E., and A. Teberosky. 1979. Los sistemas de escritura en el desarrollo del niño [Writing Systems in Children Development]. México: Siglo XXI.

Finch, A. E. 2001. "Complexity in the Language Classroom." Secondary Education Research 47: 105-140.

Fisher, C. 1996. "Les savoirs grammaticaux des élèves du primaire: le cas de l'adjectif [The Grammatical Knowledge of Primary Pupils: The Case of the Adjective]." In Pour un nouvel enseignement de la grammaire [Towards a new Instruction of Grammar], edited by dir. S.-G. Chartrand, 315-340. Québec: Les Éditions Logiques.

Fisher, C. 2004. "La place des représentations des apprenants en didactique de la grammaire [The Role of Learners' Representations in Grammar Pedagogy]." In Langue et études de la langue. Approches linguistiques et didactiques [Language and Language Studies. Linguistic and Pedagogical Approaches], edited by dir. C. Vargas, 383-393. Aix-en-Provence: Publications de l'Université de Provence.

Fontich, X. 2006. Hablar y escribir para aprender gramática [Talking and Writing to Learn Grammar]. Barcelona: ICE-Horsori.

Freeman, D., and Y. Freeman. 1998. "Preparing Teachers to Teach about Language." In Lessons to Share, edited by C. Weaver, 279-292. Portsmouth, NH: Heinemann.

French, R. 2010. "Primary School Children Learning Grammar: Rethinking the Possibilities." In Beyond the Grammar Wars. A Resource for Teachers and Students on Developing Language Knowledge in the English/Literacy Classroom, edited by T. Locke, 206-229. New York: Routledge.

Gombert, J. E. 1990. Le développement métalinguistique [Metalinguistic Development]. Paris: PUF.

González Nieto, L. 2001. Teoría lingüística y enseñanza de la lengua (lingüística para profesores) [Linguistic Theory and Language Instruction (Linguistics for Teachers)]. Madrid: Cátedra.

Gonzalvo, L., and A. Camps. 2003. "Els conceptes metalingüístics dels alumnes de secundària: el subjecte [Metalinguistic Concepts of Secondary Students: The Subject]." Articles de didàctica de la llengua i la literatura 31: 111-123.

Granott, N. 2005. "Scaffolding Dynamically toward Change: Previous and New Perspectives." New Ideas in Psychology 23 (3): 140-151.

Guasch, O. 1995. "Ús lingüístic i reflexió metalingüística en l'ensenyament i l'aprenentatge de segones llengües [Language use and Metalinguistic Reflection in Second Language Learning and Instruction]." Articles de Didàctica de la Llengua i la Literatura 6: 117-124.

Guasch, O. 2001. L'escriptura en segones llengües [Writing Composition in Second Language]. Barcelona: Graó.

Guasch, O. Forthcoming. "Interlinguistic reflection on teaching and learning languages." In Teaching Languages in a Multilingual Context. The Catalan Case, edited by J. Arnau, 15-30. Clevedon: Multilingual Matters/Institut d'Estudis Catalans.

Hakkarainen, K., and S. Paavola. 2009. "Toward a Trialogical Approach to Learning." In Transformation of Knowledge Through Classroom Interaction, edited by B. Schwarz, T. Dreyfus, and R. Hershkowitz, 65-80. London: Routledge. 
Halliday, M. A. K., and J. Webster. 2007. Text Linguistics: The How and Why of Meaning. Equinox: Equinox Textbooks and Surveys in Linguistics.

Halté, J.-F. 1998. "L'espace didactique et la transposition [Didactic Space and Transposition]." Pratiques 97-98: 171-192.

Helasvuo, M.-L. 2009. "Emergent Grammar." In Grammar, Meaning and Pragmatics, edited by F. Brisard, J.-O. Östman, and J. Verschueren, 66-73. Amsterdam: John Benjamins.

Hillocks, G., Jr., and M. W. Smith. 2003. "Grammar and Literacy Learning." In Handbook on Teaching the Language Arts, edited by J. Flood, J. M. Jensen, D. Lapp, and J. R. Squire, 721-737. New York: Macmillan.

Horning, A. 2006. "Professional Writers and Revision." In Revision. History, Theory, and Practice, edited by A. Horning and A. Becker, 117-41. West Lafayette: Parlor Press.

Hudson, R. 2001. Grammar Teaching and Writing Skills: the Research Evidence. Syntax in the Schools, 17: 1-6. Accessed September 23, 2012. http://www.phon.ucl.ac.uk/home/dick/papers/writing.htm

Hung, D. W. L. 1999. "Activity, Apprenticeship and Epistemological Appropriation: implications from the Writings of Michael Polanyi." Educational Psychologist 34 (4): 193-205.

Jakobson, R. 1960. "Closing Statement: Linguistics and Poetics." In Style in Language, edited by T. A. Sebeok, 350-377. Cambridge, MA: MIT Press.

James, C. 2002. "La conciencia sobre el lenguaje: orígenes, problemas y orientaciones [Language Awareness: Origins, Problems, and Orientations]." In Pensar lo dicho. La reflexión sobre la lengua y la comunicación en el aprendizaje de lenguas [Thinking about what we say. Reflection on Language and Communication in Language Learning], edited by J. M. Cots and L. Nussbaum, 19-32. Lleida. Milenio.

Janks, H. 2010. "Language as a System of Meaning Potential: The Reading and Design of Verbal Texts." In Beyond the Grammar Wars. A Resource for Teachers and Students on Developing Language Knowledge in the English/Literacy Classroom, edited by T. Locke, 151-169. New York: Routledge.

Karmiloff-Smith, A. 1986. "From Metaprocesses to Conscious Access: Evidence from Children's Metalinguistic and Repair Data." Cognition 23 (2): 95-147.

Karmiloff-Smith, A. 1992. "The Child as Linguist." In Beyond modularity. A Developmental Perspective on Cognitive Science, edited by A. Karmiloff-Smith, 31-63. Cambridge, MA: MIT Press.

Keefer, M., C. M. Zeitz, and L. B. Resnick. 2000. "Judging the Quality of Peer-led Student Dialogues." Cognition and Instruction 18 (1): 53-81.

Kilcher-Hagedorn, H., C. Othenin-Girard, and G. de Weck. 1987. Le savoir grammatical des élèves [Students Grammar Knowledge]. Berne: Peter Lang.

Killgallon, D., and J. Killgallon. 2006. Grammar for Middle School: A Sentencecomposing Approach. Portsmouth: Heinemann.

Kolln, M., and L. Gray. 2010. Rhetorical Grammar. Grammatical Choices, Rethorical Effects. London: Longman.

Larsen-Freeman, D. 2003. Teaching Language: From Grammar to Grammaring. Boston, MA: Thomson-Heinle.

Levelt, W. J. M. 1983. "Monitoring and Self-repair in Speech." Cognition 14: 41-104.

Locke, T. 2009. "Grammar and Writing. The International Debate." In The SAGE Handbook of Writing Development, edited by R. Beard, D. Myhill, J. Riley, and M. Nystrand, 182-193. London: SAGE.

Locke, T. 2010. "Discovering a Metalanguage for All Seasons: Bringing Literary Language in from the Cold." In Beyond the Grammar Wars. A Resource for Teachers and Students on Developing Language Knowledge in the English/Literacy, edited by T. Locke, 170-184. New York: Routledge. 
Long, M. 1991. "Focus on Form: A Design Feature in Language Teaching Methodology." In Foreign Language Research in Cross-cultural Perspective, edited by coords. K. de Bot, R. Ginsberg, and C. Kramsch, 39-52. Amsterdam: John Benjamins.

Manacorda de Rossetti, M. 1964. La gramática estructural en la escuela secundaria: su valor formativo [Structural Grammar in Secondary School: Its Formative Value]. Buenos Aires: Kapelusz.

Martin, D. 1999. "La terminologie grammaticale à l'école: facilitateur ou obstacle aux apprentissages? L'exemple de la suite du verbe [Grammar Terminology in School: A Facilitator or an Obstacle for Learning?]. In La terminologie grammaticale à l'école: perspectives interlinguistiques [Grammar Terminology in School: Interlinguistic Perspectives], edited by M. J. Béguelin, J. F. de Pietro, and A. Näf, 13-35. Institute de linguistique: Université de Neuchâtel.

Mascolo, M.F. 2005. "Change Process in Development: The Concept of Coactive Scaffolding." New Ideas in Psychology 23: 185-196.

Mercer, N. 2000. Words and Minds: How We Use Language to Think Together. London: Routledge.

Mercer, N. 2008. "Talk and the Development of Reasoning and Understanding." Human Development 51 (1): 90-100. doi: 10.1159/000113158.

Mercer N., and K. Littleton. 2007. Dialogue and the Development of Children's Thinking. A Sociocultural Approach. New York: Routledge.

Michaels, S., M. C. O'Connor, M. W. Hall, and L. B. Resnick. 2002. Accountable Talk: Classroom Conversation that Works (3 CD-ROM set). Pittsburgh, PA: University of Pittsburgh.

Milian, M., and A. Camps. 2006. "El razonamiento metalingüístico en el marco de secuencias didácticas de gramàtica (SDG) [Metaliguistic Reasoning within Grammar Didactic Sequences (GDS)]." In Diálogo e investigación en las aulas [Dialogue and Research in Classrooms], edited by coord. A. Camps, 25-54. Barcelona. Graó.

Morenberg, M., D. Daiker, and A. Kerek. 1978. "Sentence Combining at the College Level: An Experimental Study." Research in the Teaching of English 12: 245256.

Myhill, D. 2000. "Misconceptions and Difficulties in the Acquisition of Metalinguistic Knowledge." Language and Education 14 (3): 151-163. doi: 10.1080/09500780008666787.

Myhill, Debra, Susan M. Jones, Helen Lines, and Annabel Watson. 2012. "Re-thinking

Grammar: the Impact of Embedded Grammar Teaching on Students' Writing and Students' Metalinguistic Understanding." Research Papers in Education 27 (2): 139-166. doi: 10.1080/02671522.2011.637640.

Nadeau, M., and C. Fisher. 2006. La grammaire nouvelle. La comprendre et l'enseigner [New Grammar. To Understand and to Teach It]. Montréal: GaëtanMorin.

Nadeau, M., and C. Fisher. 2011. Les connaissances implicites et explicites en grammaire: quelle importance pour l'enseignement? Quelles conséquences? [Implicit and Explicit Grammar Knowledge: What Relevance for Teaching? What Consequences?] Bellaterra Journal of Teaching and Learning Language and Literature 4 (4): 1-31. Accessed September 23, 2012. http://www.raco.cat/index.php/Bellaterra/article/view/248909/333155.

Notario, G. 1999. Publicacions sobre l'ensenyament de la gramàtica a Catalunya entre 1990 i 1999 (Màster de Recerca de Didàctica de la Llengua i la Literatura) [Publications about Grammar Instruction in Catalonia between 1990 and 1999 (Master Research on Language and Literature Didactics)]. Bellaterra: UAB.

Notario, G. 2001. "Los conceptos gramaticales de los alumnos de secundaria: el sujeto [Grammar Concepts of Secondary Students: The Subject]." In El aula como 
espacio de investigación y reflexion [Classroom as a Space for Research and Reflection], edited by coord. A. Camps, 181-193. Barcelona: Graó.

O'Keeffe, A., M. McCarthy, and R. Carter. 2007. From Corpus to Classroom: Language Use and Language Teaching. Cambridge: Cambridge University Press.

Paavola, S., and K. Hakkarainen. 2005. "The Knowledge Creation Metaphor - An Emergent Epistemological Approach to Learning." Science and Education 14: 535-557. doi: 10.1007/s11191-004-5157-0.

Paolacci, V., and C. Garcia-Debanc. 2009. "Apprendre et enseigner la grammaire aujourd'hui en français langue première. Le cas de la ponctuation en production écrite en sixième [Learning and Teaching Grammar Nowadays in French L1. The case of Punctuation in written Composition in 6th Grade]." In Didactique et enseignement, français langue maternelle, français langue seconde [Didactics and Teaching, French Mother Tongue, French Second Language], edited by J. Durand, B. Habert, and B. Laks, 548-557. Paris: Institut de Linguistique Française.

Pennington, M. 2002. "Grammar and Communication: New Directions in Theory and Practice." In New Perspectives on Grammar Teaching in Second Language Classrooms, edited by E. Hinkel and S. Fotos, 77-98. Mahwah, NJ: Lawrence Erlbaum.

Peytard, J., and E. Genouvrier. 1970. Linguistique et enseignement du français [Linguistics and the Teaching of French]. Paris: Larousse.

Piggot, T. D., and R. Barr. 2002. Designing Programmatic Interventions. In Handbook of Reading Research. Vol. 3, edited by M. Kamil, P. D. Pearson, and R. Barr, 99-108. Mahwah, NJ: Lawrence Erlbaum.

Pintó, R., J. Aliberas, and R. Gómez. 1996. "Tres enfoques de la investigación sobre concepciones alternativas [Three Perspectives of Research on Alternative Conceptions]." Enseñanza de las Ciencias 14: 221-232.

Pittard, V., and M. Martlew. 2000. "Socially-Situated Cognition and Metalinguistic Activity." In Metalinguistic Activity in Learning to Write, edited by A. Camps and M. Milian, 79-102. Amsterdam: Amsterdam University Press.

Resnick, L. B. 1999. "Making America Smarter." Education Week Century Series 18 (40): $38-40$.

Rey-Debove, J. 1978. Le métalangage [Metalanguage]. Paris: Armand Colin.

Ribas, T., coord. 1997. L'avaluació formativa en l'àrea de llengua [Assessment in Language Arts]. Barcelona: Graó.

Ribas, T., X. Fontich, and O. Guasch, eds. Forthcoming. Grammar at School: Research on Metalinguistic Activity from a Sociocultural Perspective. Brussels: Peter Lang.

Ribas, Teresa, Marta Milian, Oriol Guasch, and Anna Camps. 2002. "La composición escrita como objeto de reflexion [Written Composition as an object for Reflection]." In Pensar lo dicho. La reflexión sobre la lengua y la comunicación en el aprendizaje de lenguas [Thinking about what we say. Reflection on Language and Communication in Language Learning], edited by J. M. Cots and L. Nussbaum, 167-184. Lleida: Milenio.

Richmond, J. 1990. "What do we Mean by Knowledge About Language? In Knowledge about Language and the Curriculum, edited by R. Carter, 123-144. London: Hodder and Stoughton.

Rijlaarsdam, G., and M. Couzijn. 2000. "Stimulating Awareness of Learning in the Writing Curriculum." In Metalinguistic Activity in Learning to Write, edited by A. Camps and M. Milian, 167-202. Amsterdam: Amsterdam University Press.

Rodríguez, C., and F. Zayas. 1994. "El uso como eje organizador de la enseñanzaaprendizaje de la lengua [Use as an Organizational Axis of Language Learning and Instruction]." In Ensenyament i aprenentatge de llengües [The Learning and Instruction of Languages], edited by M. D. Usó Ballester, 183-196. Castelló: Universitat Jaume I. 
Roth, Froma P., Deborah L. Speece, Daniel H. Cooper, and Susan de la Paz. 1996. "Unresolved Mysteries: How do Metalinguistic and Narrative Skills Connect with Early Reading?" The Journal of Special Education 30 (3): 257-277.

Rutherford, W. 1987. Second Language Grammar: Teaching and Learning. London: Longman.

Schneuwly, B. 1995. "De l'utilité de la transposition didactique [On the Didactic Transposition Usefulness]." In Didactique du français. Etat d'une discipline [Didactics of French. State-of-the-Art of a Discipline], edited by J.-L. Chiss, J. David, and Y. Reuter. 47-62. Neuchâtel: Delachaux and Niestlé.

Schwartz, B., T. Dreyfus, and R. Hershkowitz. 2009. "The Nested Epistemic Actions Model for Abstraction in Context." In Transformation of Knowledge Through Classroom Interaction, edited by B. Schwartz, T. Dreyfus, and R. Hershkowitz, 11-41. London and New York: Routledge.

Sfard, A. 1998. "On Two Metaphors for Learning and the Dangers of Choosing Just One." Educational Researcher 27 (2): 4-13. doi: 10.3102/0013189X027002004.

Sfard, A. 2000. "Steering (dis)course Between Metaphor and Rigor: Using Focal Analysis to Investigate the Emergence of Mathematical Objects." Journal for Research in Mathematics Education 31 (3): 296-327.

Strong, W. 1986. Creative Approaches to Sentence Combining. Urbana, IL: ERIC and the National Council of Teachers of English.

Tharp, R. and R. Gallimore. 1988. Rousing Minds to Life. Teaching, Learning, and Schooling in Social Context. Cambridge: Cambridge University Press.

Tolchinsky, L. 2000. "Contrasting Views about the Object and Purpose of Metalinguistic Work and Reflection in Academic Writing." In Metalinguistic Activity in Learning to Write, edited by A. Camps and M. Milian, 29-48. Amsterdam: Amsterdam University Press.

Tomasello, M. 1995. Language is not an Instinct. Cognitive Development, no.10: 13156.

Tsui, A. 1997. "Awareness Raising about Classroom Interaction." In Encyclopaedia of Language Education. Volume 6: Knowledge about Language, edited by L. van Lier, and D. Corson, 183-194. Dordrecht: Kluwer.

van de Pol, J., M. Volman, and J. Beishuizen. 2011. "Patterns of Contingent Teaching in Teacher Student Interaction." Learning and Instruction 21 (1): 46-57. doi: 10.1016/j.learninstruc.2009.10.004.

van Lier, L. 1995. Introducing 'Language Awareness. Londres: Penguin.

van Lier, L. 2004. The Ecology and Semiotics of Language Learning. Dordrecht: Kluwer Academic.

van Lier, L. 2008. "The ecology of Language Learning and Sociocultural Theory." In Encyclopaedia of Language Education. Volume 9: Ecology of language, edited by A. Creese, P. Martin, and N. H. Hornberger, 53-67. New York: Springer.

Vargas, C., and F. Grossman, eds. 1996. La grammaire à l'école. Pourquoi en faire? Pour qui en faire [Grammar at School. What for? For Whom]? Special issue, Repères, no. 14. Accessed September 23, 2012. http://ife.ens-lyon.fr/editionelectronique/archives/reperes/web/fascicule.php?num_fas=270.

Vargas, C. 2004. "La création des savoirs à enseigner en grammaire: de la recomposition à la reconfiguration [The Creation of Grammar-Knowledge-to-beTaught: From Recomposition to Reconfiguration]." In Langue et études de la langue. Approches linguistiques et didactiques [Language and Language Studies Linguistic and Didactic Approaches], edited by C. Vargas, 35-48. Aixen-Provence: Publications de l'Université de Provence.

Vargas, C. 2009. "Peut-on inventer une grammaire pour la réussite scolaire? Mises en perspectives et voies de renouveau [Can we Invent a Grammar for Success in School? Perspectives and Ways to Improve]" Repères 39: 17-39.

Vygotsky, L. S. 1978. Mind in Society. Cambridge, MA: Harvard University Press. 
Walmsley, J. 1997. "Pedagogical Grammar: From Prescriptive to Descriptive." In Encyclopaedia of Language Education, Volume 6: Knowledge About Language, edited by L. van Lier and D. Corson, 11-20. Dordrecht: Kluwer Academic.

Weaver, C. 2008. Grammar to Enrich and Enhance Writing. Portsmouth, NH: Heinemann.

Wegerif, Rupert, Paolo Boero, Jerry Andriessen, and Ellice Forman. 2009. "A Dialogue on Dialogue and its Place within Education." In Transformation of Knowledge through Classroom Interaction, edited by B. Schwartz, T. Dreyfus, and R. Hershkowitz, 184-199. London and New York: Routledge.

Wegerif, R., N. Mercer, and L. Dawes. 1999. "From Social Interaction to Individual Reasoning: An Empirical Investigation of a Possible Sociocultural Model of Cognitive Development." Learning and Instruction 9 (6): 493-516.

Weigand, E. 2011. "Paradigm Changes in Linguistics: From Reductionism to Holism." Language Sciences 33: 544-549. doi: 10.1016/j.langsci.2011.04.031.

Wells, G. 1999. Dialogic Inquiry. Toward a Sociocultural Practice and Theory of Education. Cambridge: Cambridge University Press.

Wenger, E. (2009). A Social Theory of Learning. In Contemporary Theories of Learning. Learning Theorists in Their own Words, edited by, K. Illeris, 209-218. New York: Routledge.

Wood, D., J. S. Bruner, and G. Ross. 1976. "The Role of Tutoring in Problem Solving." Journal of Child Psychology and Child Psychiatry 17: 89-100.

Wyse, D. 2001. "Grammar. for Writing? A Critical Review of Empirical Evidence" British Journal of Educational Studies 49 (4): 411-427.

Zayas, F. 1997. "Las prácticas discursivas como eje para secuenciar las habilidades lingüísticas: una propuesta para la ESO [Discursive Practices as an Axis to Sequence Linguistic Abilities: A Proposal for Secondary Level]." In Didáctica de la lengua y la literatura para una sociedad plurilingüe del siglo XXI [Language and Literature Didactics for a Plurilingual Society in the 21st Century], edited by A. Mendoza, C. Romea, and F.J. Cantero, 955-962. Barcelona: Universidad de Barcelona/SEDLL.

Zayas, F. 2004. "Hacia una gramática pedagógica [Towards a Pedagogical Grammar]." Textos de didáctica de la lengua y la literatura 37: 16-35. 